\title{
Paleo Constraints on Future Sea-Level Rise
}

\author{
Andrew C. Kemp ${ }^{1}$. Andrea Dutton ${ }^{2}$. \\ Maureen E. Raymo ${ }^{3}$
}

Published online: 17 July 2015

(C) Springer International Publishing AG 2015

\begin{abstract}
Sea-level rise predicted for the twenty-first century and beyond will become increasingly hazardous to coastal populations, economies, static infrastructure, and ecosystems. Accurately predicting the magnitude and rate of future sealevel rise at local, regional, and global scales is necessary to effectively plan for and manage this growing hazard. Sea-level reconstructions show how high and how fast sea level rose when Earth's climate regime was similar to that anticipated in the immediate future. We draw upon examples from the past three million years, including the Pliocene $(\sim 3$ million years ago), the Last Interglacial period (Marine Isotope Stage 5e, $\sim 125,000$ years ago), and the Common Era (last $\sim 2000$ years) to provide a synopsis of what is known about sea-level rise during these past warm periods and highlight some of the benefits and challenges of using paleo sealevel data to predict future changes.
\end{abstract}

Keywords Pliocene $\cdot$ Last interglacial $\cdot$ Ice sheet

This article is part of the Topical Collection on Sea Level Projections

Andrew C. Kemp

andrew.kemp@tufts.edu

Andrea Dutton

adutton@ufl.edu

Maureen E. Raymo

raymo@ldeo.columbia.edu

1 Department of Earth and Ocean Sciences, Tufts University, 2 North Hill Road, Medford, MA 02176, USA

2 Department of Geological Sciences, University of Florida, 241 Williamson Hall, PO Box 112120, Gainesville, FL 32611, USA

3 Lamont Doherty Earth Observatory of Columbia University, 61 Route 9 W, P.O. Box 1000, Palisades, NY 10964, USA

\section{Introduction}

Sea-level rise will be among the most costly and destructive consequences of climate change because it threatens coastal populations, economies, static infrastructure, and ecosystems with more frequent flooding during storms and high tides [33, 67]. This vulnerability is heightened by historic and projected increases in human activity along low-lying coastlines and, in particular, at locations which are expected to experience sealevel rise in excess of the global mean or at locations which lack the physical and/or economic resources to manage future change (e.g., [106]). Although consensus exists that climate change in the twenty-first century and beyond will cause global mean sea-level (GMSL) rise, considerable uncertainty remains as to the likely magnitude and spatial variability of those changes. Using process-based models, the Intergovernmental Panel on Climate Change (IPCC) predicted a likely increase in GMSL of $0.28-0.98 \mathrm{~m}$ by $2100 \mathrm{AD}$ compared to the average observed between $1986 \mathrm{AD}$ and $2005 \mathrm{AD}$ [12]. Alternative approaches to forecasting GMSL change, some of which predict greater sea-level rise than the IPCC, include semi-empirical modeling (e.g., [79, 87]), expert elicitation (e.g., [38]), and probabilistic assessments (e.g., [44]). However, GMSL projections do not reflect the expected spatial variability of local sea-level change that will range from sea-level fall to a rise much greater than GMSL because of a range of physical processes. Developing accurate predictions of sealevel rise therefore remains a critical area of socially-relevant scientific research, particularly on the local to regional spatial scales and decadal to centennial timescales necessary for effective coastal planning and management (e.g., [68]).

The need to provide appropriate analogs for current trends, and thus constraints on future changes, is a primary motivation for reconstructing paleoenvironmental changes. The geological record provides a history of coupled climate and sea- 
level changes that occurred under a range of boundary conditions including varied paleogeographies, atmospheric $\mathrm{CO}_{2}$ concentrations, and orbital forcing regimes. Although future changes will be unique, the paleoenvironmental record includes time intervals characterized by warmer mean temperatures and smaller-thanpresent polar ice sheet configurations that offer insight into how local, regional, and global sea levels might respond to the climate changes predicted for the coming decades to centuries. In particular, the Representative Concentration Pathways (RCPs) are a series of socioeconomic scenarios that estimate future changes in the atmospheric concentration of greenhouse gases (e.g., $[59,65,101])$. The resulting forcing of the climate system can be used to estimate global temperature changes through climate models such as the Model for the Assessment of Greenhouse-gas Induced Climate Change (MAGICC; e.g., [45, 58]; Fig. 1). These scenarios serve as a guide for identifying periods in Earth's climate history that were similar to those predicted for the near future. By $2200 \mathrm{AD}, \mathrm{CO}_{2}$ concentrations reached 1829 ppm under the high-end, business-as-usual RCP 8.5 pathway, resulting in predicted global mean temperatures that are $\sim 7.6^{\circ} \mathrm{C}$ warmer than the period 1981-2010 AD. In RCP 2.6, greenhouse gas emissions are sharply curbed, resulting in a maximum $\mathrm{CO}_{2}$ concentration of $442 \mathrm{ppm}$ in $2046 \mathrm{AD}$ that declines to $384 \mathrm{ppm}$ in $2200 \mathrm{AD}$. Under this scenario, global mean temperature increases are limited to $<1{ }^{\circ} \mathrm{C}$ compared to the 1981-2010 $\mathrm{AD}$ reference period. Two other scenarios (RCP 4.5 and RCP 6) describe intermediate $\mathrm{CO}_{2}$ emission pathways and associated temperature outcomes. We review relative sea-level (RSL) reconstructions from three time periods (the Pliocene, the Last Interglacial period, and the Common Era) to estimate how high and how fast sea level rose under climate conditions similar to those predicted under the RCP scenarios for the next $\sim 200$ years. These examples illustrate some of the

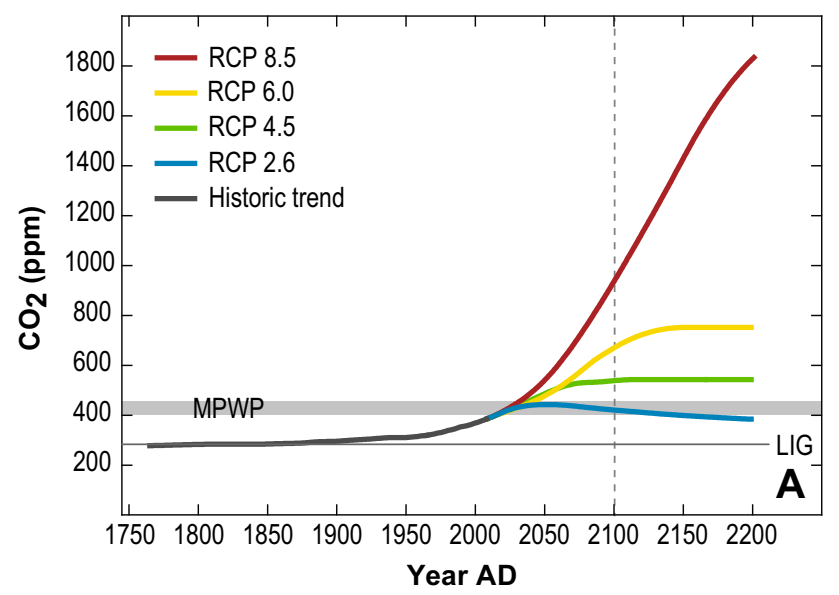

Fig. 1 a Projected changes in atmospheric concentration of $\mathrm{CO}_{2}$ under four Representative Concentration Pathways (RCPs). Estimated $\mathrm{CO}_{2}$ concentrations during the mid-Pliocene warm period (MPWP) and Last Interglacial period (LIG) are displayed as a shaded horizontal band and solid line, respectively. b Modeled changes in global mean temperature benefits and challenges of using paleo sea-level data to evaluate the likely outcome of future climate change.

\section{Relative and Global Mean Sea Level}

RSL is the difference in elevation between the sea surface and the solid Earth at a specific location and time (e.g., [25]). RSL reconstructions are based on empirical data that estimate the height of paleo sea level. The reconstruction is produced by measuring the elevation of a paleo sea-level indicator in the field with respect to a modern tidal datum such as mean tide level. Sea-level indicators are physical, chemical, or biological proxies with a systematic and quantifiable relationship to contemporary tides (e.g., [92, 99]) and include geomorphic features (e.g., [69]), coral reefs (e.g., [24]), coral microatolls (e.g., [108]), and saltmarsh plants (e.g., [103]) or micro-organisms (e.g., [41]). Each type of indicator forms or accumulates at a particular range of elevations that is termed the indicative range and that can be established by direct measurement of modern analogs (e.g., [109]).

The vertical uncertainty of a RSL reconstruction is primarily determined by the indicative range of the sea-level indicator because modern surveying techniques allow accurate and precise measurement of sample elevation. Importantly, vertical RSL errors are not systematically larger for older reconstructions, although paleo tidal range change is rarely corrected for $[32,91]$ and often introduces an unquantified uncertainty. To reconstruct $\mathrm{RSL}$, the paleo sea-level indicator is also dated, either directly through radiometric methods (e.g., ${ }^{14} \mathrm{C}$ or U-series), by correlation with an existing timescale such as marine oxygen isotope stages and magnetic reversals, or by correlation to other chronologies using biostratigraphy or chemostratigraphy.

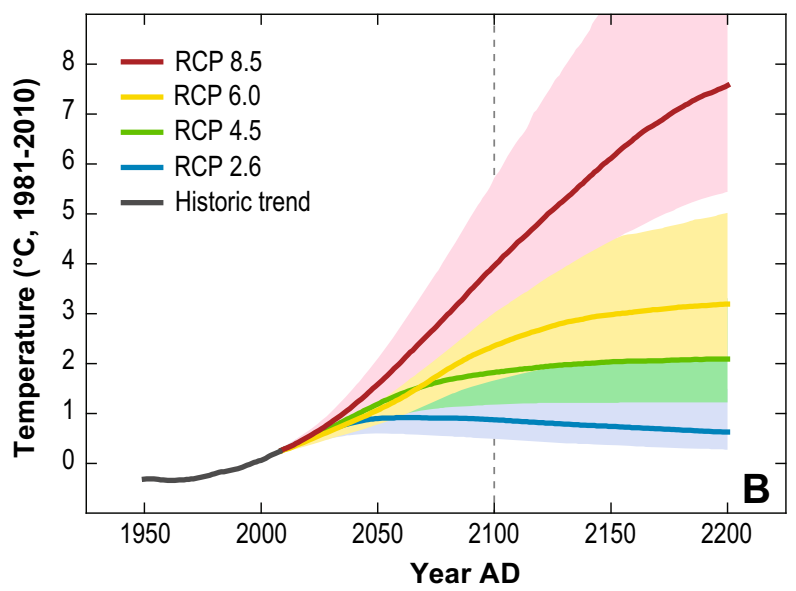

compared to the 1981-2010 AD reference period using the forcings proscribed by the four RCPs. Solid lines represent the 50th percentile result from the MAGICC climate model, and shaded envelopes are the corresponding $67 \%$ confidence interval (reproduced from [45]) 
The resulting RSL reconstructions are characterized by age and sea-level uncertainties and have incomplete and uneven coverage in time and space resulting in temporal gaps and a limited distribution of locations. Since projections focus on relatively short timescales (typically $<200$ years), reconstructions with small chronological and sea-level uncertainties are often sought as direct analogs for future sea-level change. However, longer (e.g., multi-century) projections are valuable for exploring scenarios of maximum possible sea-level rise, estimating the commitment to sea-level rise beyond the stabilization of greenhouse gas emissions, setting emission caps, and developing long-term adaptation strategies. The multicentennial lag time from climate forcing to GMSL achieving a new equilibrium is the primary reason that projections for the next 100-200 years are less than GMSL reconstructions from periods where atmospheric $\mathrm{CO}_{2}$ was less than, or similar to, present $[26,28,52,83]$. Therefore, paleo constraints on future sea-level rise should also include coarser and more extreme sea-level reconstructions that capture the full equilibrium response of GMSL to climate forcing.

Sea-level rise projections commonly focus on GMSL as the quantity to be forecast. This variable is a convenient construct, but local and regional RSL can depart significantly from GMSL. Over long periods of time, even very slow processes can cause multi-meter displacement of the sea-level indicators used to reconstruct RSL. Differences between local RSL and GMSL arise because of (1) processes causing vertical land motion such as tectonics (e.g., [1, 104]) and sediment compaction (e.g., [10, 61]); (2) factors that alter the height of the solid Earth and the geoid, such as glacio-isostatic adjustment (e.g., $[25,74])$, the gravitational fingerprint of ice sheet mass loss (static equilibrium effect; [34, 64]), and crustal topographic differences arising from mantle convection and differences in continental buoyancy (termed dynamic topography; e.g., [31, 66, 85, 86]); and (3) changes associated with dynamic processes such as ocean circulation that cause sea level to differ from the geoid (e.g., [110]). The contribution from all of these processes is variable in time and space. We examine the role and relative magnitude of these processes as drivers of paleo sea-level changes and the need to quantify their contribution to local RSL reconstructions in order to estimate GMSL.

\section{Glacio-Isostatic Adjustment}

Loading and unloading of land-based ice during glacials and interglacials cause deformation of the solid Earth and alteration of the geoid in response to the changing distribution of water and ice mass. This response is termed glacio-isostatic adjustment (GIA) and can cause local RSL to depart from GMSL. The contribution of GIA to RSL can be large (meters to tens of meters on timescales of hundreds to thousands of years), non-linear through time, and spatially variable. Therefore, it is critical to understand and quantify GIA in order to transform RSL reconstructions into estimates of GMSL. Locations close to contemporary or former ice sheets experience a larger contribution from GIA than far-field locations that will record RSL changes closer to GMSL (e.g., [14, 25]). The contribution of GIA to a local RSL reconstruction can be estimated using an Earth-ice model (e.g., $[5,16,49,63,74])$. The "Earth" component simulates the geophysical response to loading and unloading and is partly constrained by the assumed structure and viscosity of the mantle. The "ice" model describes the evolving distribution and volume of land-based ice in time and space and can be varied independently of the Earth model. Models of Earth structure and ice history are commonly coupled to make RSL hindcasts, and therefore, the uncertainties in each model are often underestimated. Corrections for GIA from Earth-ice models are most sensitive to the choice of Earth model (e.g., mantle viscosity), particularly in regions located close to former ice sheets such as the US Atlantic coast (e.g., [82]). RSL reconstructions provide data for testing and constraining Earth-ice models. For example, databases of Holocene sea-level index points provide a calibration target for Earth models that can inform the decision to choose one mantle viscosity profile over another [23, 62, 90]. The ability to reproduce reconstructed Holocene RSL trends is a valuable test of Earth-ice models that are applied to earlier time periods (see, for example, "The Pliocene" section). Similarly, spatially-dispersed RSL reconstructions can help to constrain ice models by fingerprinting meltwater sources [43, 64].

A key result from these models is that Earth's response to deglaciation continues for thousands of years after ice retreat, making RSL reconstructions sensitive to earlier phases of ice sheet behavior. This is illustrated by tide-gauge measurements of local RSL changes which show the displacement of the tide gauge by GIA at a linear rate over the historic period (e.g., [13]). For example, The Battery tide gauge in New York City measured a RSL rise since the mid-nineteenth century, while the tide gauge in Oslo, Norway, measured a RSL fall during the twentieth century (Fig. 2). The ICE-5G (VM2) Earth-ice model [75] estimates that GIA contributed $+1.22 \mathrm{~mm} /$ year (RSL rise) to the measured RSL trend in New York City and $-4.21 \mathrm{~mm} /$ year (RSL fall) in Oslo. This is a first-order contribution that must be removed before one can estimate a GMSL trend driven by climate change. GIA makes an ongoing contribution to measured RSL trends because Earth's response to deglaciation since the Last Glacial Maximum (LGM; Marine Isotope Stage 2) is incomplete. Knowing the volume and distribution of ice at the LGM is therefore a prerequisite for accurately estimating current GMSL trends and for reconstructing paleo GMSL (e.g., [2, 51, 76]). The influence of GIA is increasingly problematic and complex for older RSL reconstructions that experienced multiple and unique phases of glaciation and 


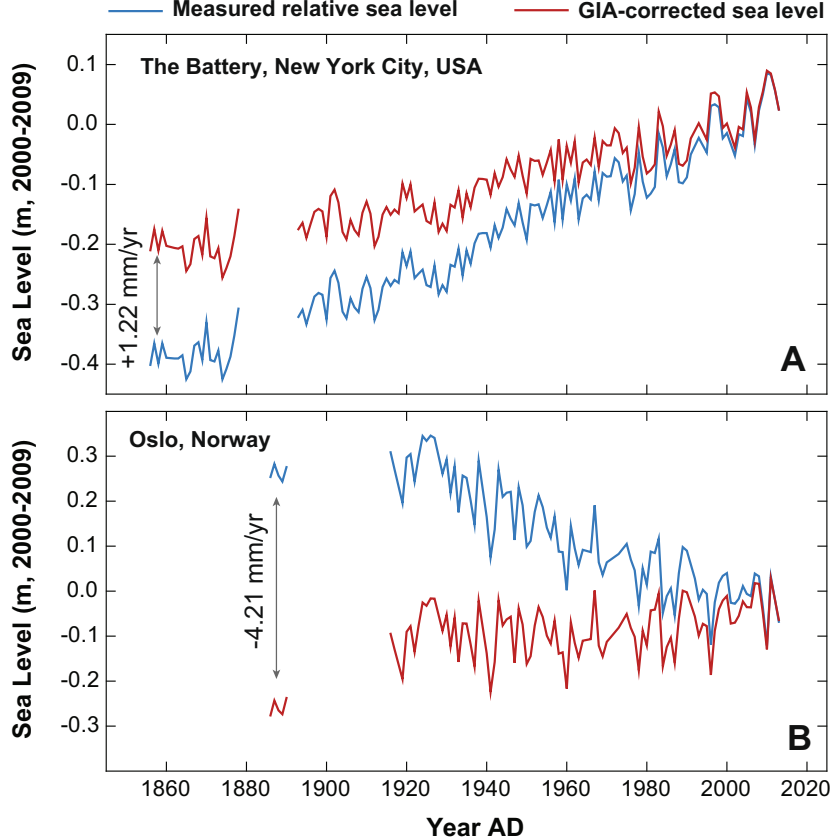

Fig. 2 Example of the contribution from glacio-isostatic adjustment (GIA) to historic, local relative sea-level trends measured by tide gauges in a New York City, USA, and b Oslo, Norway. GIA estimates are from the ICE-5G (VM2) Earth-ice model [75] and provided by the Permanent Service for Mean Sea Level

deglaciation between which isostatic equilibrium may, or may not, have been achieved. Evidence of ice distribution prior to the LGM is difficult to estimate because subsequent glaciations often destroy, rework, or otherwise overprint the physical evidence of prior glaciations. However, RSL reconstructions from warmer periods are most strongly influenced by the relaxation of Earth's surface and gravity field since the LGM and also the relative state of relaxation achieved during the unique climate cycle being examined [20, 81, 82]. In effect, RSL reconstructions from a previous warm period vary spatially due to GIA and must be corrected for this contribution to effectively estimate paleo GMSL.

\section{The Pliocene}

During the Pliocene epoch (5.33-2.58 Ma), peak atmospheric $\mathrm{CO}_{2}$ concentrations were $\sim 400 \mathrm{ppm}$ and possibly reached $450 \mathrm{ppm}$ based on reconstructions from alkenones in marine algae [72, 88], the density of leaf stomata [100], and stable isotopes of carbon and boron measured in marine sediment $[4$, $80,89]$. These $\mathrm{CO}_{2}$ concentrations are similar to those predicted under the RCP 2.6 scenario (Fig. 1a) and measured in the current atmosphere, although the current climate system (including temperature and the volume of land-based ice) is yet to achieve a new equilibrium with the present, elevated concentration of $\mathrm{CO}_{2}$ in the atmosphere. Temperature reconstructions and climate modeling indicate that Earth was 2-
$4{ }^{\circ} \mathrm{C}$ warmer than preindustrial temperatures during the middle Pliocene (e.g., [11, 18, 19, 36, 37]), which is similar to predictions for the end of the twenty-first century under the RCP 8.0 and RCP 6.0 scenarios (Fig. 1b). The stacked oxygen isotope record of Lisiecki and Raymo [53] shows that three "super interglacials" occurred between 3.3 and $2.9 \mathrm{Ma}$. These times likely corresponded to times of maximum GMSL height, minimum ice sheet extent, and also (presumably) the highest $\mathrm{CO}_{2}$ concentrations and surface temperatures of the mid-Pliocene warm period (Fig. 3a).

Pliocene RSL has been reconstructed using estimates of global ice volume from the temperature-corrected oxygen isotope composition of foraminifera and ostracods (e.g., [42, 96]), from the height of erosional features caused by sealevel fluctuations such as disconformities on atolls (e.g., [105]), and using paleoshoreline deposits. For example, Dowsett and Cronin [17] recognized the Duplin Formation ( $\sim 85 \mathrm{~m}$ above modern sea level) in the southeastern USA as a mid-Pliocene warm period marine deposit based on micropaleontological evidence. The RSL reconstruction was corrected for post-depositional uplift at $0.5-2.0 \mathrm{~cm} / \mathrm{kyr}$ to estimate that GMSL was $35 \pm 18 \mathrm{~m}$ above present.

Estimating GMSL during the Pliocene is problematic because the time elapsed since the formation of the sea-level indicators is $\sim 3$ million years. This allows even very gradual processes such as dynamic topography to create differences between reconstructed RSL and GMSL of up to tens of meters $[66,86]$. Pliocene RSL reconstructions are also influenced by ongoing GIA to numerous, post-depositional glacial-interglacial cycles (Fig. 3a), although the largest and most influential contribution comes from last glacial cycle [82]. Rovere et al. [85] compiled and standardized Pliocene RSL reconstructions from South Africa, Australia, and the southeastern USA and removed a contribution from GIA that was estimated using a suite of Earth models and an assumed ice history (Fig. 3b). The remaining sea-level changes were primarily the result of GMSL change and dynamic topography. Partitioning of this sea-level rise was investigated using GMSL scenarios of 0,14 (Fig. 3c), 22, and $30 \mathrm{~m}$ (Fig. 3d) in which the assumed configuration of ice sheets results in spatial variability of sea-level change caused by ice sheet growth since the mid-Pliocene warm period. The remaining sea-level change was attributed to dynamic topography. From this study, it is clear that uncertainty in regional patterns of dynamic topography is the single greatest obstacle to deriving an accurate estimate of GMSL from Pliocene RSL reconstructions.

Despite these uncertainties, the most recent IPCC assessment of paleo sea level concluded with high confidence that Pliocene GMSL was $>0$ and $<20 \mathrm{~m}$ above present [56]. We believe that this assessment is at odds with the magnitude of the uncertainties in GIA, dynamic topography, and temperature-corrected calcite measurements. If all of the current Greenland ice sheet deglaciated (a GMSL rise of $\sim 7 \mathrm{~m}$; 
Fig. 3 a Stacked oxygen isotope measurements from cores of marine sediment [53]. b Relative sea-level reconstructions (grey symbols) from South Africa, Australia, and the southeastern USA compiled and standardized by Rovere et al. [85]. The reconstructions were corrected for glacio-isostatic adjustment (GIA) using the average contribution estimated from a suite of Earth models (colored symbols) under an assumed ice history that begins with no Pliocene ice in West Antarctica and Greenland and scales subsequent ice volume changes relative to the oxygen isotope record shown in a (see [82] for complete details). c, $\mathbf{d}$ Partitioning of the remaining sealevel change between dynamic topography and global mean sea level under two possible scenarios of ice sheet development at the end of the Pliocene. The scenarios specify the height of global mean sea level ( $14 \mathrm{~m}$ in $\mathbf{c}$ and $30 \mathrm{~m}$ in d) and calculate the spatial variability in its expression resulting from the assumed configuration of ice sheets
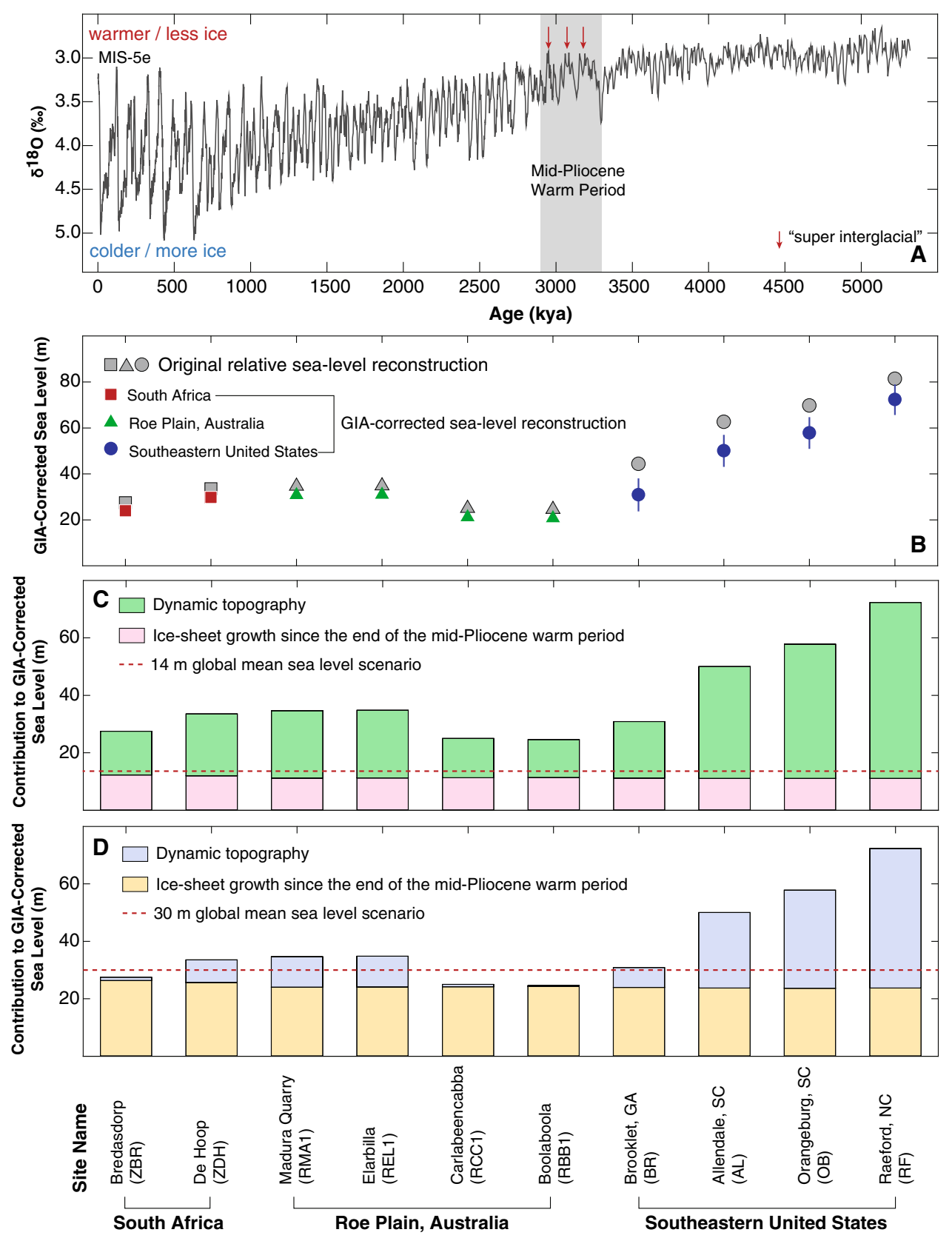

[3]), as well as all of West Antarctica ( $\sim 5 \mathrm{~m}$; [29]), and we added 2-3 $\mathrm{m}$ for steric effects and crustal rebound under West Antarctica [82], the IPCC assessment suggests that $<5 \mathrm{~m}$ of deglaciation likely occurred in East Antarctica during the peak warmth of the Pliocene (out of $\sim 52 \mathrm{~m}$ GMSL equivalent; [54]). Given recent physical evidence suggesting that the East Antarctic ice sheet may have experienced partial retreat during parts of the early to middle Pliocene [15, 73], we feel that it is premature to rule out the possibility of a much more dynamic East Antarctic ice sheet. One solution to the problem of trying to simultaneously understand GMSL change, GIA, and dynamic topography during and since the Pliocene is to increase the number and spatial distribution of RSL reconstructions. With a large matrix of reconstructions, it should be possible to derive a GMSL scenario that is most consistent with model predictions of GIA and dynamic topography that uses a unique and internally consistent set of physical conditions [82, 85].

\section{The Last Interglacial Period ( 125 ka)}

The late Quaternary was characterized by periodic waxing and waning of ice sheets in the Northern Hemisphere, during which 
atmospheric $\mathrm{CO}_{2}$ concentrations varied from $\sim 180$ to $200 \mathrm{ppm}$ during glacials to $\sim 280 \mathrm{ppm}$ during interglacials (e.g., [94]). Marine Isotope Stage (MIS) 5e represents the peak interglacial climate conditions of the Last Interglacial (LIG) period. Although the peak LIG $\mathrm{CO}_{2}$ concentration of $\sim 285 \mathrm{ppm}$ (e.g., [77]) is considerably less than that of the present ( $\sim 400$ ppm; Fig. 1a), polar temperatures were warmer than preindustrial conditions and comparable to those projected for the twenty-first century (e.g., [60, 71, 77]). This pattern was caused by orbital forcing with larger eccentricity than during the Holocene interglacial and a different phasing of the precession and obliquity components [6]. Reconstructions of the peak height of LIG sea level and the nature of sealevel rise (e.g., gradual or abrupt rates of change) can therefore shed light on the dynamic and equilibrium response of ice sheets in Greenland and Antarctica when subjected to prolonged warming (e.g., $[20,46,47,70])$.

A common approach to reconstructing LIG sea level is using U-Th dated corals that grew close to sea level in tropical locations such as the Bahamas [98] or Western Australia [97]. Despite being located in tropical locations that are far from the margins of former ice sheets, RSL in these regions is still affected by Earth's response to deglaciations through a combination of glacio- and hydro-isostatic processes (e.g., $[20,46,50]$ ) and coralbased reconstructions must therefore be corrected for isostatic (and sometimes also tectonic) contributions as a necessary step in interpreting data and estimating past GMSL.
The peak GMSL attained during the LIG period was recently estimated using global ([20, 46, 47]; Fig. 4) and regional compilations of RSL reconstructions $[21,70]$ that were corrected for the contribution from GIA. These studies concluded that maximum GMSL during the LIG period was $~ 6-$ $9 \mathrm{~m}$ above present, which is higher than the previous longstanding estimate of 4-6 m based on data that was not corrected for GIA (e.g., [7, 97]). Hay et al. [34] argued that the 5.5-9-m range proposed by Dutton and Lambeck [20] that is partially based on reconstructions from the Seychelles likely overestimates GMSL by up to $15 \%$ because sea-level rise in the Seychelles would be higher than the global average regardless of which polar ice sheet(s) collapsed. Consideration of this sea-level fingerprint revises the GMSL estimate from the Seychelles to $7.6 \pm 1.7 \mathrm{~m}$, which remains in agreement with a 6-9-m range of peak sea level [21]. Agreement in peak sea level between this suite of studies, despite differences in data and approach, implies some robustness to the interpretation, but the 3-m range is still large relative to the ice equivalent masses of the West Antarctic and Greenland ice sheets (see previous section). A combination of data and models suggests that a significant fraction of the Greenland ice sheet remained intact throughout the LIG period, limiting its contribution to $\sim 2 \mathrm{~m}$ (North Greenland Eemian Ice Drilling Community [60]). With a possible combined contribution of $\sim 1 \mathrm{~m}$ from thermal expansion and melting of mountain glaciers [57, 78], this implies that a significant contribution to LIG GMSL must have come from Antarctic ice melt. However, direct observational evidence from the Antarctic region to confirm this
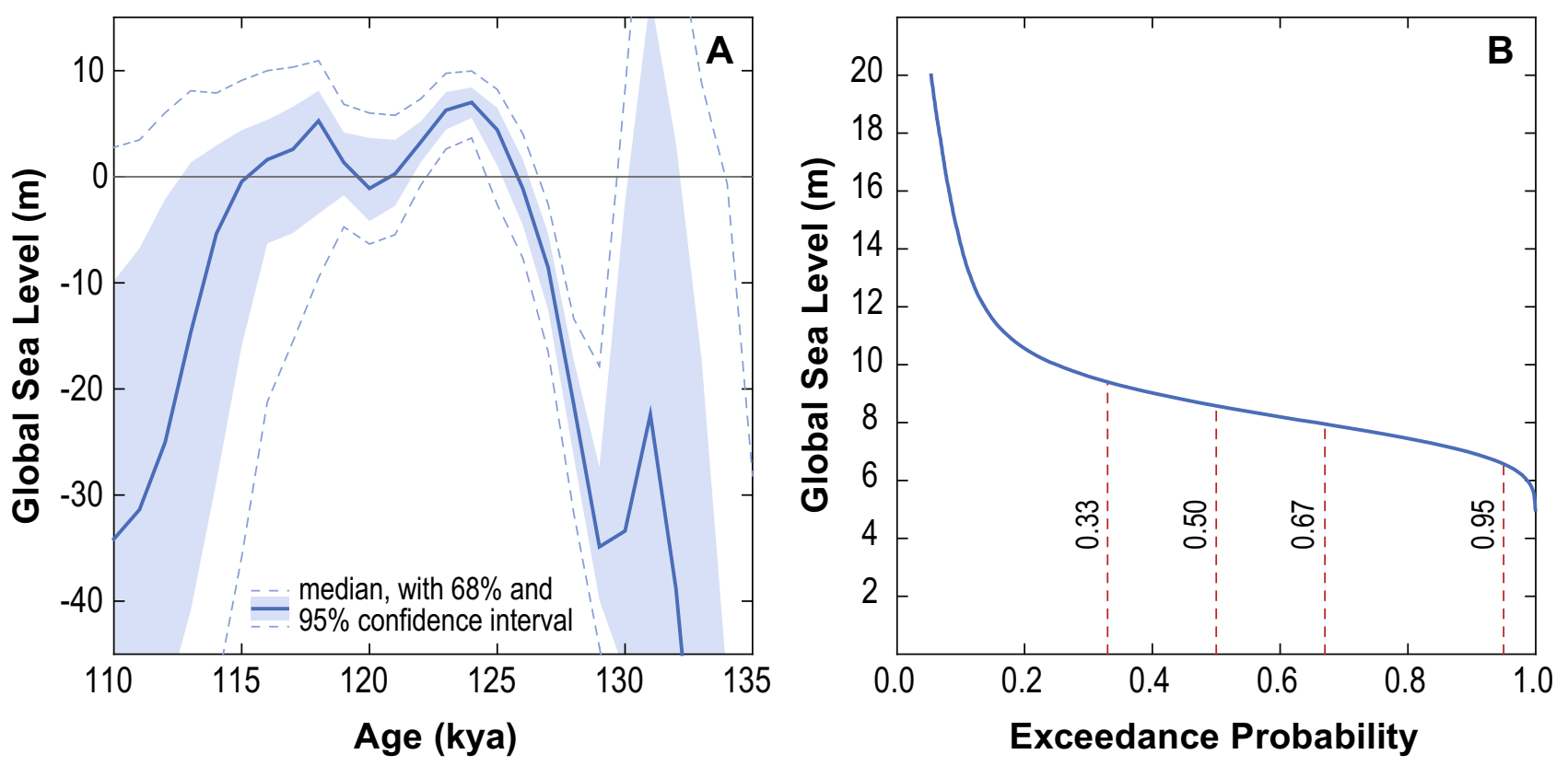

Fig. 4 a Probabilistic assessment of global sea level during the Last Interglacial based on a compilation of published RSL reconstructions. b Likelihood that Last Interglacial exceeded heights expressed in meters above present. Modified from [46] 
interpretation of polar ice sheet mass loss is currently lacking. Additional RSL reconstructions in mid- to high-latitude regions will provide valuable constraints toward partitioning mass balance contributions from Greenland and Antarctica.

Although there is high confidence that LIG ice sheets were smaller than present, no consensus exists on the timing of Antarctic ice sheet retreat within the span of the LIG sealevel highstand (compare, for example, [9, 21, 70]). This is an important constraint on the future response of ice sheets and sea-level rise because it sets limits on potential rates of change as well as lag times between forcing and response. A debate also surrounds whether multiple GMSL oscillations occurred during the LIG sea-level highstand [9, 46, 84, 98]. Resolving the number, timing, and causes of sub-orbital sealevel oscillations smaller than $\sim 10 \mathrm{~m}$ during the LIG highstand is important for establishing the potential for dynamic behavior of polar ice sheets. In particular, understanding the climatic conditions associated with partial Antarctic ice sheet collapse and constraining rates of GMSL change during polar ice sheet retreat remain key challenges for this time interval that have potential to inform projections of future sea-level change under sustained warming.

\section{The Common Era (The Last 2000 Years)}

Common Era RSL reconstructions are largely derived from salt marsh sediment (e.g., [27, 41]), coral microatolls (e.g., $[107,108]$ ), and archaeological remains (e.g., [48, 95]). Common Era GMSL variability was probably less than $\pm 0.25 \mathrm{~m}$ around a stable sea level (order of tenths of $\mathrm{mm} /$ year for rates of change) until the onset of historic, accelerated modern rates of rise $[12,35]$. Although this period is not a direct analog for future changes, highly resolved Common Era sea-level reconstructions can be paired with contemporary temperature reconstructions (e.g., [55]) to look in detail at the response of sea level to climate forcing on timescales (multi-decadal to multi-centennial) and magnitudes similar to those that are the focus of climate and sea-level projections. This makes them well suited to understanding the relationship between climate and sea level and constraining future trends for four reasons. Firstly, the dynamic co-evolution of temperature and sea-level changes (including lag times) is constrained by a continuous time series. This is in contrast to proxy data from other periods when discrete sea-level and temperature reconstructions for a single time point could actually be up to several thousand years different in age due to chronological uncertainties. Secondly, the precision of Common Era sea-level and temperature reconstructions is comparable to the warming and sea-level rise anticipated for the next 100-200 years. Thirdly, Common Era sea-level reconstructions include the response to both warming (e.g., the Medieval Climate Anomaly) and cooling (e.g., the Little Ice Age) phases. Fourthly, the
GIA contribution to Common Era RSL reconstructions is comparatively well constrained and approximately linear over this interval (e.g., [22, 93]). It can be estimated using an Earthice model or a linear trend fitted to regional compilations of RSL reconstructions spanning the last 2000-4000 years, but excluding the twentieth century. Both approaches assume that meltwater input was negligible during that time interval and that Common Era RSL trends were solely (Earth-ice models) or primarily (proxy reconstructions) driven by GIA. The Earth-ice model approach is able to estimate GIA where suitable geological data are unavailable and is well suited to comparing among reconstructions. Using linear RSL trends inherently captures land-level changes driven by processes other than GIA (e.g., tectonics and dynamic topography) and does not rely on accurately modeling paleo ice distributions or parameterizing Earth models. Since Common Era sealevel variability was relatively small, the chosen rate of GIA correction significantly influences reconstructed sealevel trends. Therefore, the choice of GIA correction is non-trivial and consequently influences the inferred sensitivity of sea-level to climate forcing. Future work should aim to incorporate uncertainty and non-linearity through time into the GIA corrections applied to Common Era RSL reconstructions.

Common Era RSL reconstructions provide valuable constraints on predictive models. Processed-based models estimate the individual contributions to sea-level rise (e.g., melting of glaciers, ice caps and ice sheets, and the increasing volume of existing ocean water as it warms) that are summed to predict the magnitude of future GMSL rise and are reliant upon an accurate understanding of each contribution. For example, sea-level projections in IPCC AR4 [7] omitted any contribution from rapid, dynamical ice sheet change because it was poorly understood. Scientific progress between AR4 and AR5 enabled the IPCC to make likely projections of GMSL by including an estimate of this contribution [12].

Semi-empirical models offer a pragmatic, alternative approach that projects sea level by linking the rate of sea-level rise to global temperature [30, 79, 102]. They are calibrated with past temperature and sea-level data and then project GMSL under a scenario of future temperature change. The choice of calibration period therefore influences model projections. Compared to the historical record (last $\sim 150$ years), Common Era sea-level and temperature reconstructions offer a longer calibration interval that includes periods of warming and cooling (e.g., [30, 79, 102]). Bittermann et al. [8] showed that combining a regional, GIA-corrected RSL reconstruction from North Carolina [41] with global tide-gauge data [39] provided a more robust model calibration than using either sea-level data set in isolation. To date, semiempirical models developed using paleo sea-level 
reconstructions have (from necessity) combined local-to regional-scale sea-level data with global temperature reconstructions (e.g., [41]). Even after correction for GIA, these models retain the influence of regional-scale processes such as ocean dynamics or the fingerprint of ice sheet melting that could cause departures from GMSL. For example, differences in centennial and regionalscale Common Era sea-level trends between New Jersey and Florida on the US Atlantic coast were attributed to variability in the position and/or strength of the Gulf Stream by Kemp et al. [40].

As the number and distribution of Common Era RSL reconstructions grows, it will be possible to produce a more robust estimate of GMSL for use alongside global temperature reconstructions in predictive semi-empirical models. This approach explicitly assumes a constant relationship between temperature and the rate of sea-level rise through time. The validity of this assumption is likely to be challenged for future scenarios of climate change where sealevel change is increasingly driven by mass contributions from Antarctic and Greenland melting that played a smaller role during the model calibration period.

\section{Conclusions}

The need to provide local- to regional-scale sea-level projections for the coming decades and centuries remains a critical area of socially-relevant scientific research because of the growing concentration of socioeconomic activity along coastlines globally. In the absence of a historical record of a time when global mean sea level (GMSL) was higher than present, relative sea-level (RSL) reconstructions during past warm periods help us to understand the nature and timing of ice sheet and GMSL response to temperatures similar to those predicted for the future. Importantly, understanding past, present, and future GMSL trends relies on accurately partitioning the causes of reconstructed, local RSL change including GIA and mantle dynamic topography. This remains a primary challenge for using paleo sea-level changes as a constraint on future trends.

Although past warm periods are imperfect analogs for future climate, GMSL reconstructions during the Last Interglacial period (LIG; Marine Isotope Stage 5e) and the Pliocene suggest that the Greenland and Antarctic ice sheets are yet to achieve equilibrium with the present climate. This interpretation rests on the observation that even with atmospheric $\mathrm{CO}_{2}$ levels lower than today (during the LIG period), GMSL was likely at least 6-9 m higher than today. This is significantly higher than projections for the twenty-first century, indicating a possible commitment to significant, multi-century GMSL rise as polar ice sheets gradually reach a new equilibrium. Importantly, GMSL of 6-9 $\mathrm{m}$ above present can only be attained through a considerable reduction of land-based ice volume in Greenland and/or Antarctica. Therefore, understanding polar climates during previous warm periods will help to constrain the boundary conditions necessary for such ice sheet retreat. Additionally, understanding how quickly ice sheet retreat and GMSL rise can occur is one of the most societally relevant pieces of information that sea-level reconstructions can bring to bear on projections for the future and should therefore remain a high priority for research. Common Era reconstructions demonstrate that sea level can respond rapidly to climate change as evidenced by the late nineteenth- or early twentieth-century increase in the rate of sea-level rise from a long-term background pattern characterized by slow variability (tenths of $\mathrm{mm} /$ year) around a relatively stable mean, to average twentieth-century rates of rise of $\sim 1.7 \mathrm{~mm} /$ year and a current rate of rise $>3 \mathrm{~mm} /$ year (e.g., [12, 35, 41]). In particular, highly resolved Common Era sea-level reconstructions can be paired with contemporary temperature reconstructions to understand their co-evolution on the decadal and century timescales that are important for coastal planning.

The present spatial and temporal distribution of RSL reconstructions is incomplete and highly uneven. Additional RSL reconstructions from key periods including the LIG period, the Pliocene, and the Common Era will increasingly help to constrain paleo GMSL estimates that are internally consistent with one another as well as with model predictions of physical processes such as GIA and dynamic topography. Ideally, these models should fit a global array of RSL reconstructions using a unique set of physical conditions and assumptions including the volume and distribution of land-based ice masses in the past as well as mantle viscosity and convection through time. Ultimately, these paleo constraints will help us to project how high and how fast GMSL will rise as a consequence of ongoing climate change and how sea level will vary among regions. Therefore, an iterative synergy between field-based RSL reconstructions and modeling of physical processes should remain a research priority if we are to effectively plan for and manage the threat posed by sea-level rise to coastal populations.

Acknowledgments We thank Bob Kopp and Klaus Bittermann for providing the MAGICC climate projections and two anonymous reviewers for their helpful and insightful comments. This is a contribution to the PaleoConstraints on Sea-Level Rise (PALSEA2) working group. We acknowledge support from NSF award OCE-1202632 "PLIOMAX" to MER, NSF award \#1155495 to AD, and NOAA award NA11OAR4310101 to ACK.

Conflict of Interest On behalf of all authors, the corresponding author states that there is no conflict of interest. 


\section{References}

1. Atwater BF. Evidence for great Holocene earthquakes along the outer coast of Washington state. Science. 1987;236:942-4.

2. Austermann J, Mitrovica JX, Latychev K, Milne GA. Barbadosbased estimate of ice volume at Last Glacial Maximum affected by subducted plate. Nat Geosci. 2013;6:553-7.

3. Bamber JL, Layberry RL, Gogineni SP. A new ice thickness and bed data set for the Greenland ice sheet: 1. Measurement, data reduction, and errors. J Geophys Res: Atmos. 2001;106: 33773-80.

4. Bartoli G, Hönisch B, Zeebe RE. Atmospheric CO2 decline during the Pliocene intensification of northern hemisphere glaciations. Paleoceanography. 2011;26:PA4213.

5. Bassett SE, Milne GA, Mitrovica JX, Clark PU. Ice sheet and solid earth influences on far-field sea-level histories. Science. 2005;309: 925-8.

6. Berger A, Loutre MF. Insolation values for the climate of the last 10 million years. Quat Sci Rev. 1991;10:297-317.

7. Bindoff NL, Willebrand J, Artale VAC, Gregory J, Gulev S, Hanawa $\mathrm{K}$, et al. Observations: oceanic climate change and sea level. In: Solomon S, Qin D, Mannin M, Chen Z, Marquis M, Avery KB, Tignor M, Miller HL, editors. Climate change 2007: the physical science basis. Contribution of Working Group I to the Fourth Assessment Report of the Intergovernmental Panel on Climate Change. Cambridge: Cambridge University Press; 2007.

8. Bittermann K, Rahmstorf S, Perrette M, Vermeer M. Predictability of twentieth century sea-level rise from past data. Environ Res Lett. 2013;8:014013.

9. Blanchon P, Eisenhauer A, Fietzke J, Liebetrau V. Rapid sea-level rise and reef back-stepping at the close of the last interglacial highstand. Nature. 2009;458:881-4.

10. Bloom AL. Peat accumulation and compaction in Connecticut coastal marsh. J Sediment Res. 1964;34:599-603.

11. Brierley CM, Fedorov AV, Liu Z, Herbert TD, Lawrence KT, LaRiviere JP. Greatly expanded tropical warm pool and weakened Hadley circulation in the early Pliocene. Science. 2009;323: 1714-8.

12. Church, J.A., Clark, P.U., Cazenave, A., Gregory, J.M., Jevrejeva, S., Levermann, A., Merrifield, M.A., Milne, G.A., Nerem, R.S., Nunn, P.D., Payne, A.J., Pfeffer, W.T., Stammer, D., Unnikrishnan, A.S. (2013). Sea-level change. In: Stocker, T.F., D. Qin, D., Plattner, G.K., Tignor, M., Allen, S.K., Boschung, J., Nauels, A., Xia, Y., Bex, V., Midgley, P.M. (Eds.), Climate change 2013: the physical science basis. Contribution of Working Group I to the Fifth Assessment Report of the Intergovernmental Panel on Climate Change (pp. 1137-1216). Cambridge University Press.

13. Church JA, White NJ. Sea-level rise from the late 19th to the early 21st century. Surv Geophys. 2011;32:585-602.

14. Clark JA, Farrell WE, Peltier WR. Global changes in postglacial sea level: a numerical calculation. Quat Res. 1978;9:265-87.

15. Cook CP, van de Flierdt T, Williams T, Hemming SR, Iwai M, Kobayashi M, et al. Dynamic behaviour of the East Antarctic ice sheet during Pliocene warmth. Nat Geosci. 2013;6:765-9.

16. Davis JL, Mitrovica JX. Glacial isostatic adjustment and the anomalous tide gauge record of eastern North America. Nature. 1996;379:331-3.

17. Dowsett HJ, Cronin TM. High eustatic sea level during the middle Pliocene: evidence from the southeastern U.S. Atlantic coastal plain. Geology. 1990;18:435-8.

18. Dowsett HJ, Robinson MM, Foley KM. Pliocene threedimensional global ocean temperature reconstruction. Clim Past. 2009;5:769-83.
19. Dowsett HJ, Robinson MM, Haywood AM, Hill DJ, Dolan AM, Stoll DK, et al. Assessing confidence in Pliocene sea surface temperatures to evaluate predictive models. Nat Clim Chang. 2012;2: 365-71.

20. Dutton A, Lambeck K. Ice volume and sea level during the last interglacial. Science. 2012;337:216-9.

21. Dutton A, Webster JM, Zwartz D, Lambeck K, Wohlfarth B. Tropical tales of polar ice: evidence of last interglacial polar ice sheet retreat recorded by fossil reefs of the granitic Seychelles islands. Quat Sci Rev. 2015;107:182-96.

22. Engelhart SE, Horton BP, Douglas BC, Peltier WR, Tornqvist TE. Spatial variability of late Holocene and 20th century sea-level rise along the Atlantic coast of the United States. Geology. 2009;37: 1115-8.

23. Engelhart SE, Peltier WR, Horton BP. Holocene relative sea-level changes and glacial isostatic adjustment of the U.S. Atlantic coast. Geology. 2011;39:751-4.

24. Fairbanks RG. A 17, 000-year glacio-eustatic sea level record: influence of glacial melting rates on the Younger Dryas event and deep-ocean circulation. Nature. 1989;342:637-42.

25. Farrell WE, Clark JA. On postglacial sea level. Geophys J R Astron Soc. 1976;46:647-67.

26. Foster GL, Rohling EJ. Relationship between sea level and climate forcing by $\mathrm{CO} 2$ on geological timescales. Proc Natl Acad Sci. 2013;110:1209-14.

27. Gehrels WR, Kirby JR, Prokoph A, Newnham RM, Achterberg EP, Evans $\mathrm{H}$, et al. Onset of recent rapid sea-level rise in the western Atlantic ocean. Quat Sci Rev. 2005;24:2083-100.

28. Goelzer H, Huybrechts P, Raper SCB, Loutre MF, Goosse H, Fichefet T. Millennial total sea-level commitments projected with the Earth system model of intermediate complexity LOVECLIM. Environ Res Lett. 2012;7:045401.

29. Gomez N, Mitrovica JX, Tamisiea ME, Clark PU. A new projection of sea level change in response to collapse of marine sectors of the Antarctic Ice Sheet. Geophys J Int. 2010;180:623-34.

30. Grinsted A, Moore JC, Jevrejeva S. Reconstructing sea level from paleo and projected temperatures 200 to 2100 AD. Clim Dyn. 2009;34:461-72.

31. Hager BH, Clayton RW, Richards MA, Comer RP, Dziewonski AM. Lower mantle heterogeneity, dynamic topography and the geoid. Nature. 1985;313:541-5.

32. Hall GF, Hill DF, Horton BP, Engelhart SE, Peltier WR. A highresolution study of tides in the Delaware Bay: past conditions and future scenarios. Geophys Res Lett. 2013;40:338-42.

33. Hallegatte S, Green C, Nicholls RJ, Corfee-Morlot J. Future flood losses in major coastal cities. Nat Clim Chang. 2013;3:802-6.

34. Hay C, Mitrovica JX, Gomez N, Creveling JR, Austermann J, Kopp E, et al. The sea-level fingerprints of ice-sheet collapse during interglacial periods. Quat Sci Rev. 2014;87:60-9.

35. Hay, C., Morrow, E., Kopp, R.E., Mitrovica, J.X. (2015). Probabilistic reanalysis of twentieth-century sea-level rise. Nature.

36. Haywood AM, Hill DJ, Dolan AM, Otto-Bliesner BL, Bragg F, Chan WL, et al. Large-scale features of Pliocene climate: results from the Pliocene model intercomparison project. Clim Past. 2013;9:191-209.

37. Haywood AM, Valdes PJ, Sellwood BW. Global scale palaeoclimate reconstruction of the middle Pliocene climate using the UKMO GCM: initial results. Glob Planet Chang. 2000;25: 239-56.

38. Horton BP, Rahmstorf S, Engelhart SE, Kemp AC. Expert assessment of sea-level rise by AD 2100 and AD 2300. Quat Sci Rev. 2014;84:1-6. 
39. Jevrejeva S, Moore JC, Grinsted A, Woodworth PL. Recent global sea level acceleration started over 200 years ago? Geophys Res Lett. 2008;35:L08715.

40. Kemp AC, Bernhardt CE, Horton BP, Vane CH, Peltier WR, Hawkes $\mathrm{AD}$, et al. Late Holocene sea- and land-level change on the U.S. Southeastern Atlantic coast. Mar Geol. 2014;357: 90-100.

41. Kemp AC, Horton B, Donnelly JP, Mann ME, Vermeer M, Rahmstorf S. Climate related sea-level variations over the past two millennia. Proc Natl Acad Sci. 2011;108:11017-22.

42. Kennett JP, Hodell DA. Stability or instability of Antarctic ice sheets during warm climates of the Pliocene. GSA Today. 1995;5:10-3.

43. Kopp RE. Palaeoclimate: Tahitian record suggests Antarctic collapse. Nature. 2012;483:549-50.

44. Kopp RE, Horton RM, Little CM, Mitrovica JX, Oppenheimer M, Rasmussen DJ, et al. Probabilistic 21st and 22nd century sea-level projections at a global network of tide-gauge sites. Earth's Futur. 2014;2:383-406.

45. Kopp RE, Rasmussen DJ. Technical appendix: physical climate projections. In: Houser T, Kopp RE, Hsiang S, Muir-Wood R, Larsen K, Delgado M, Jina A, Wilson P, Mohan S, Rasmussen DJ, Mastrandrea M, Rising J, editors. American climate prospectus: economic risks in the United States. New York: Rhodium Group; 2014.

46. Kopp RE, Simons FJ, Mitrovica JX, Maloof AC, Oppenheimer M. Probabilistic assessment of sea level during the last interglacial stage. Nature. 2009;462:863-7.

47. Kopp RE, Simons FJ, Mitrovica JX, Maloof AC, Oppenheimer M. A probabilistic assessment of sea level variations within the last interglacial stage. Geophys J Int. 2013;193:711-6.

48. Lambeck K, Anzidei M, Antonioli F, Benini A, Esposito A. Sea level in roman time in the central Mediterranean and implications for recent change. Earth Planet Sci Lett. 2004;224:563-75.

49. Lambeck K, Chappell J. Sea level change through the last glacial cycle. Science. 2001;292:679-86.

50. Lambeck K, Nakada M. Constraints on the age and duration of the last interglacial period and on sea-level variations. Nature. 1992;357:125-8.

51. Lambeck K, Rouby H, Purcell A, Sun Y, Sambridge M. Sea level and global ice volumes from the last glacial maximum to the Holocene. Proc Natl Acad Sci. 2014;111:15296-303.

52. Levermann A, Clark PU, Marzeion B, Milne GA, Pollard D, Radic V, et al. The multimillennial sea-level commitment of global warming. Proc Natl Acad Sci. 2013;110:13745-50.

53. Lisiecki LE, Raymo ME. A Pliocene-Pleistocene stack of 57 globally distributed benthic $\delta 180$ records. Paleoceanography. 2005;20:PA1003.

54. Lythe MB, Vaughan DG. BEDMAP: a new ice thickness and subglacial topographic model of Antarctica. J Geophys Res: Solid Earth. 2001;106:11335-51.

55. Mann ME, Zhang Z, Hughes MK, Bradley RS, Miller SK, Rutherford S, et al. Proxy-based reconstructions of hemispheric and global surface temperature variations over the past two millennia. Proc Natl Acad Sci. 2008;105:13252-7.

56. Masson-Delmonte, V., Schulz, M., Abe-Ouchi, A., Beer, J., Ganopolski, A., González Rouco, J.F., Jansen, E., Lambeck, K., Luterbacher, J., Naish, T., Osborn, T., Otto-Bliesner, B., Quinn, T., Ramesh, R., Rojas, M., Shao, X., Timmermann, A., (2013). Information from Paleoclimate Archives. In: Stocker, T.F., D. Qin, D., Plattner, G.K., Tignor, M., Allen, S.K., Boschung, J., Nauels, A., Xia, Y., Bex, V., Midgley, P.M. (Eds.), Climate change 2013: the physical science basis. Contribution of Working Group I to the Fifth Assessment Report of the Intergovernmental Panel on Climate Change (pp. 383-464). Cambridge University Press.
57. McKay NP, Overpeck JT, Otto-Bliesner BL. The role of ocean thermal expansion in Last Interglacial sea level rise. Geophys Res Lett. 2011;38:L14605.

58. Meinshausen M, Raper SCB, Wigley TML. Emulating coupled atmosphere-ocean and carbon cycle models with a simpler model, MAGICC6 - part 1: model description and calibration. Atmos Chem Phys. 2011;11:1417-56.

59. Meinshausen M, Smith SJ, Calvin K, Daniel JS, Kainuma MLT, Lamarque JF, et al. The RCP greenhouse gas concentrations and their extensions from 1765 to 2300. Clim Chang. 2011;109: 213-41.

60. Members NGEIDC. Eemian interglacial reconstructed from a Greenland folded ice core. Nature. 2013;493:489-94.

61. Miller, K.G., Kopp, R.E., Horton, B.P., Browning, J.V., Kemp, A.C., (2013). A geological perspective on sea-level rise and its impacts along the U.S. mid-Atlantic coast. Earth's Futur.

62. Milne GA, Long AJ, Bassett SE. Modelling Holocene relative sealevel observations from the Caribbean and South America. Quat Sci Rev. 2005;24:1183-202.

63. Milne GA, Peros M. Data-model comparison of Holocene sealevel change in the circum-Caribbean region. Glob Planet Chang. 2013; 107:119-31.

64. Mitrovica JX, Tamisiea ME, Davis JL, Milne GA. Recent mass balance of polar ice sheets inferred from patterns of global sealevel change. Nature. 2001;409:1026-9.

65. Moss RH, Edmonds JA, Hbbard KA, Manning MR, Rose SK, van Vuuren DP, et al. The next generation of scenarios for climate change research and assessment. Nature. 2010;463:747-56.

66. Moucha R, Forte AM, Mitrovica JX, Rowley DB, Quéré S, Simmons NA, et al. Dynamic topography and long-term sea-level variations: there is no such thing as a stable continental platform. Earth Planet Sci Lett. 2008;271:101-8.

67. Nicholls RJ, Cazenave A. Sea-level rise and its impact on coastal zones. Science. 2010;328:1517-20.

68. Nicholls RJ, Hanson SE, Lowe JA, Warrick RA, Lu X, Long AJ. Sea-level scenarios for evaluating coastal impacts. Wiley Interdiscip Rev Clim Chang. 2014;5:129-50.

69. O'Leary MJ, Hearty PJ, McCulloch MT. Geomorphic evidence of major sea-level fluctuations during marine isotope substage-5e, Cape Cuvier, Western Australia. Geomorphology. 2008;102: 595-602.

70. O'Leary MJ, Hearty PJ, Thompson WG, Raymo ME, Mitrovica JX, Webster JM. Ice sheet collapse following a prolonged period of stable sea level during the last interglacial. Nat Geosci. 2013;6: 796-800.

71. Otto-Bliesner BL, Marshall SJ, Overpeck JT, Miller GH, Hu A, Members C.L.I.P. Simulating arctic climate warmth and icefield retreat in the Last Interglaciation. Science. 2006;311:1751-3.

72. Pagani M, Liu Z, LaRiviere J, Ravelo AC. High Earth-system climate sensitivity determined from Pliocene carbon dioxide concentrations. Nat Geosci. 2010;3:27-30.

73. Patterson MO, McKay R, Naish T, Escutia C, Jimenez-Espejo FJ, Raymo ME, et al. Orbital forcing of the East Antarctic ice sheet during the Pliocene and Early Pleistocene. Nat Geosci. 2014;7: 841-7.

74. Peltier WR. Global sea level rise and glacial isostatic adjustment: an analysis of data from the east coast of North America. Geophys Res Lett. 1996;23:GL00848.

75. Peltier WR. Global glacial isostasy and the surface of the ice-age Earth: the ICE-5G (VM2) model and GRACE. Annu Rev Earth Planet Sci. 2004;32:111-49.

76. Peltier WR, Fairbanks RG. Global glacial ice volume and Last Glacial Maximum duration from an extended Barbados sea level record. Quat Sci Rev. 2006;25:3322-37. 
77. Petit JR, Jouzel J, Raynaud D, Barkov NI, Barnola JM, Basile I, et al. Climate and atmospheric history of the past 420,000 years from the Vostok ice core, Antarctica. Nature. 1999;399:429-36.

78. Radić V, Hock R. Regional and global volumes of glaciers derived from statistical upscaling of glacier inventory data. J Geophys Res: Earth Surf. 2010;115:F01010.

79. Rahmstorf S. A semi-empirical approach to projecting future sealevel rise. Science. 2007:315:368-70.

80. Raymo ME, Grant B, Horowitz M, Rau GH. Mid-Pliocene warmth: stronger greenhouse and stronger conveyor. Mar Micropaleontol. 1996;27:313-26.

81. Raymo ME, Mitrovica JX. Collapse of polar ice sheets during the stage 11 interglacial. Nature. 2012;483:453-6.

82. Raymo ME, Mitrovica JX, O’Leary MJ, DeConto RM, Hearty PJ. Departures from eustasy in Pliocene sea-level records. Nat Geosci. 2011;4:328-32.

83. Rohling EJ, Grant K, Bolshaw M, Roberts AP, Siddall M, Hemleben C, et al. Antarctic temperature and global sea level closely coupled over the past five glacial cycles. Nat Geosci. 2009;2:500-4

84. Rohling EJ, Grant K, Hemleben C, Siddall M, Hoogakker BAA, Bolshaw M, et al. High rates of sea-level rise during the last interglacial period. Nat Geosci. 2008;1:38-42.

85. Rovere A, Raymo ME, Mitrovica JX, Hearty PJ, O’Leary MJ, Inglis JD, The Mid-Pliocene sea-level conundrum: glacial isostasy, eustasy and dynamic topography. Earth Planet Sci Lett. 2014;387:27-33.

86. Rowley DB, Forte AM, Moucha R, Mitrovica JX, Simmons NA, Grand SP. Dynamic topography change of the eastern United States since 3 million years ago. Science. 2013;340:1560-3.

87. Schaeffer M, Hare W, Rahmstorf S, Vermeer M. Long-term sealevel rise implied by $1.5^{\circ} \mathrm{C}$ and $2{ }^{\circ} \mathrm{C}$ warming levels. Nat Clim Chang. 2012;2:867-70.

88. Seki O, Foster GL, Schmidt DN, Mackensen A, Kawamura K, Pancost RD. Alkenone and boron-based Pliocene pCO2 records. Earth Planet Sci Lett. 2010;292:201-11.

89. Seki O, Foster GL, Schmidt DN, Mackensen A, Kawamura K, Pancost RD. Alkenone and boron-based Pliocene pCO2 records. Earth Planet Sci Lett. 2010;292:201-11.

90. Shennan I, Horton B. Holocene land-and sea-level changes in Great Britain. J Quat Sci. 2002;17:511-26.

91. Shennan I, Lambeck K, Flather R, Horton B, McArthur J, Innes J, et al. Modelling western North Sea palaeogeographies and tidal changes during the Holocene. In: Shennan I, Andrews J, editors. Holocene land-ocean interaction and environmental change around the North Sea. London: Geological Society Special Publications; 2000. p. 299-319.

92. Shennan, I., Long, A.J., Horton, B.P., (2015). Handbook of sealevel research. (p. 600) Wiley-Blackwell.

93. Shennan I, Milne G, Bradley S. Late Holocene vertical land motion and relative sea-level changes: lessons from the British Isles. J Quat Sci. 2012;27:64-70.

94. Sigman DM, Boyle EA. Glacial/interglacial variations in atmospheric carbon dioxide. Nature. 2000;407:859-69.
95. Sivan D, Lambeck K, Toueg R, Raban A, Porath Y, Shirman B. Ancient coastal wells of Caesarea Maritima, Israel, an indicator for relative sea level changes during the last 2000 years. Earth Planet Sci Lett. 2004;222:315-30.

96. Sosdian S, Rosenthal Y. Deep-sea temperature and ice volume changes across the Pliocene-Pleistocene climate transitions. Science. 2009;325:306-10.

97. Stirling CH, Esat TM, Lambeck K, McCulloch MT. Timing and duration of the Last Interglacial: evidence for a restricted interval of widespread coral reef growth. Earth Planet Sci Lett. 1998;160: $745-62$.

98. Thompson WG, Allen Curran H, Wilson MA, White B. Sea-level oscillations during the last interglacial highstand recorded by Bahamas corals. Nat Geosci. 2011;4:684-7.

99. van de Plassche O. Sea-level research: a manual for the collection and evaluation of data. Norwich: Geobooks; 1986.

100. van der Burgh J, Visscher H, Dilcher DL, Kürschner WM. Paleoatmospheric signatures in Neogene fossil leaves. Science. 1993;260:1788-90.

101. van Vuuren D, Edmonds J, Kainuma M, Riahi K, Thomson A, Hibbard $\mathrm{K}$, et al. The representative concentration pathways: an overview. Clim Chang. 2011;109:5-31.

102. Vermeer M, Rahmstorf S. Global sea level linked to global temperature. Proc Natl Acad Sci. 2009;106:21527-32.

103. Waller, M., (2015). Techniques and applications of plant macrofossil analysis in sea-level studies, In: Shennan, I., Long, A.J., Horton, B.P. (Eds.), Handbook of sea-level research. (pp. 183190) Wiley-Blackwell.

104. Wang P-L, Engelhart SE, Wang K, Hawkes AD, Horton BP, Nelson AR, et al. Heterogeneous rupture in the great Cascadia earthquake of 1700 inferred from coastal subsidence estimates. J Geophys Res: Solid Earth. 2013;118:2460-73.

105. Wardlaw BR, Quinn TM. The record of Pliocene sea-level change at Enewetak Atoll. Quat Sci Rev. 1991;10:247-58.

106. Wong PP, Losada IJ, Gattuso JP, Hinkel J, Khattabi A, McInnes $\mathrm{KL}$, et al. Coastal systems and low-lying areas. In: Field CB, Barros VR, Dokken DJ, Mach KJ, Mastrandrea MD, Bilir TE, Chatterjee M, Ebi KL, Estrada YO, Genova RC, Girma B, Kissel ES, Levy AN, MacCracken S, Mastrandrea PR, White LL, editors. Climate change 2014: impacts, adaptation, and vulnerability. Part a: global and sectoral aspects. Contribution of Working Group II to the Fifth Assessment Report of the Intergovernmental Panel on Climate Change. Cambridge: Cambridge University Press; 2014. p. 361-409.

107. Woodroffe C, McLean R. Microatolls and recent sea level change on coral atolls. Nature. 1990;344:531-4.

108. Woodroffe CD, McGregor HV, Lambeck K, Smithers SG, Fink D. Mid-pacific microatolls record sea-level stability over the past 5000 yr. Geology. 2012;40:951-4.

109. Woodroffe, S., Barlow, N.L.M., (2015). Reference water level and tidal datum. In: Shennan, I., Long, A.J., Horton, B.P. (Eds.), Handbook of sea-level research. (pp. 171-182) Wiley-Blackwell.

110. Yin J, Schlesinger ME, Stouffer RJ. Model projections of rapid sea-level rise on the northeast coast of the United States. Nat Geosci. 2009;2:262-6. 